\title{
Assembling a Blue Economy moment? Geographic engagement with globalizing biological-economic relations in multi-use marine environments
}

Dialogues in Human Geography 2017, Vol. 7(I) 3-26

(C) The Author(s) 2017 Reprints and permission: sagepub.co.uk/journalsPermissions.nav DOI: $10.1177 / 2043820617691643$ journals.sagepub.com/home/dhg

@SAGE

\author{
Gordon M Winder \\ LMU Munich, Germany \\ Richard Le Heron \\ University of Auckland, New Zealand
}

\begin{abstract}
In the 2010s, the 'Blue Economy' has been widely advocated by a spectrum of interests as a strategy to save the world's oceans and water. This article explores what the Blue Economy moment is and how geographers can engage with it. It acknowledges recent efforts by geographers to understand Blue Economy but goes further by outlining the European Union's Blue Economy programmes and by discussing these in relation to recent agenda setting in marine science. We argue that in spite of apparent convergence on this goal, the Blue Economy imaginary disciplines disparate knowledge for economic projects, when the planetary reality is that every economic project is axiomatically a biological project, with some economic aspects. In this context, the article outlines how assemblage thinking could be relevant to a human geography engagement with Blue Economy and what this could like, and how a relational conception of Blue Economy helps advance understanding. Finally, we discuss the difficulties and potential for human geographers to be genuinely enactive given the disciplinary framings that have already been assumed or imposed through Blue Economy. This last is highlighted by discussing engagement in a particular New Zealand Blue Economy initiative. Rather than either promoting or critiquing Blue Economy, we encourage informed and critical engagement with Blue Economy by geographers.
\end{abstract}

\section{Keywords}

assemblage, bioeconomic, Blue Economy, coast, European Union, fisheries, human geography, marine environment, New Zealand, ocean

\section{Introduction}

This article is an intervention in geographic knowledge production, in the spirit of Castree et al.'s (2014: 472-474) call for geographers to actively
Corresponding author:

Gordon M Winder, Department of Geography, LMU Munich, Luisenstrasse 37, Munich 80333, Bavaria, Germany.

Email: gordon.winder@Imu.de 
engage in remaking global and situated environmental knowledge, by working to change conceptions of what should be debated, the terms under which debate is conducted, and, we would add, the strategies for enactive engagement in existing and new processes. Our focus is the so-called Blue Economy and our aim is to conceptually elaborate how it is known and made. The Blue Economy has been widely advocated in the 2010 s as a strategy to 'save' the world's oceans and water. Enrolling oceans, coasts and land in new economic possibilities changes the places, scales and dynamics by which natural resources enter into economic systems. This interest comes when nations and the international and legal community are confronting multiple and overlapping uses in ocean and marine environments (Arkema et al., 2006; Ban et al., 2013) and not simply separate uses, such as fishing or mining, each administered separately. These are in fact colliding in coastal and marine space (e.g. Winder and Rees, 2010).

Vanguard studies by geographers of the Blue Economy are evident. They have noted that the ocean, once an inhospitable place for humans, is now viewed as equivalent to a land based resource system, to be managed, allocated and developed as property, and governed through market mechanisms (Mansfield, 2004, 2007; Munroe et al., 2014). They identify ocean grabbing (Bennett et al., 2015), warn about artificial demarcation of territory in fisheries management (Rossiter et al., 2015) and reveal the contested Blue Economy discourses that are emerging (Silver et al., 2015). In an as yet unrelated move, other geographers working on marine questions are exploring the metaphors, connectivities and mobilities, ontologies and materialities of oceans and thus challenging the ways in which we construct and know the world (Anderson and Peters, 2014; Ogborn, 2005; Peters, 2010; Steinberg, 2013; Winder, 2006). We draw inspiration from this diverse work to map the emerging meanings and practices of Blue Economy and the challenges that it presents. We use geographic assemblage ideas to help make more visible the multiple ontologies of investment institutional initiatives and the particular economic-environment relations invoked, established and stabilized with Blue Economy imagining.
This brings into view the diverse, situated, valuesmeans-ends pathways or ontologies that are being constituted in the name of Blue Economy and the knowledge politics at play.

The emergence of Blue Economy discourses, their scope and discernible features and geographers' responses to the discourses are first discussed. This involved a literature review and a search of activities and events in 2014 associated with Blue Economy. The findings enable a descriptive mapping of the discourses and actors involved. Partly to balance recent work on the emergence of Blue Economy within Small Island Development States (SIDS) circles (Silver et al., 2015), special attention is given to the European Union's (EU's) work to promote its sustainable seas ambitions through definition and management of Europe's Blue Economy. There are many other important centres for Blue Economy policy, including China, the United States, Indonesia and SIDS, but the EU's established policy framework allows us to highlight economic and scientific implications of the assembling work being done there under the Blue Economy rubric: It is in fact an economy that is being planned.

Acknowledging the diverse contexts in which the Blue Economy is at work, we then consider issues germane to developing an assemblage approach aimed at foregrounding biological and economic relationalities in Blue Economy initiatives and thinking. This is followed by a conceptual schematic of Blue Economy activities that, in breaking with scientific knowledge production traditions, aids relational thinking on reterritorializing human and nonhuman entanglements in coasts, seas and oceans. Finally, we shift from descriptive scoping and conceptual concerns to an example of the assembling of a Blue Economy research initiative, advocated by New Zealand human geographers in that country's science funding framework. This section outlines challenges that can arise when human geographers engage with other experts, investors, stakeholders and government over a new generation of ocean issues associated with Blue Economy, admittedly under one neoliberal governance regime.

Our main aim is to energize a dialogue on how to engage with Blue Economy initiatives. We argue 
that by considering the Blue Economy as diverse investment institutional projects, each assembling specific gazes on the oceans, geographers can pinpoint how each initiative addresses bioeconomic relations, what ethical and political challenges of dealing with ocean space they entail and how bioeconomic relations can be made differently under Blue Economy relations. We contend that it is through this kind of approach that geographers will be able to offer and engage in multiple strands of intellectual leadership in the complex spaces being imagined under the Blue Economy rubric.

\section{An emergent Blue Economy}

Blue Economy has emerged in diverse discourses and contexts, and therefore, it is not easy to define what the term means. By documenting and discussing activities, events and actors using this term, we offer a mapping of the emerging Blue Economy. The term has currency within United Nations (UN) circles (Silver et al., 2015), appears in EU, Chinese government, and other institutional settings, and has been adopted and promoted by a range of commercial, expert and scientific actors. Thus, we conceive of the term as a rubric around which constellations of actors assemble for diverse purposes and in specific contexts. It is important to note that our mapping cannot be definitive, though it illustrates both the diverse interpretations and contestations of the term, and specific assemblying work around the term.

Blue Economy imagining inspires optimism and anticipation. Suggestions of developed governmental practice and of inter-institutional support come from the SIDS process, the Global Oceans Commission, the Global Partnership for Oceans and the place of oceans in the UN's Action Agenda 20122016. Here, the 'Blue Economy, founded in line with the concept and principles of, and mutually supportive with the Green Economy, is a tool that appears to offer specific mechanisms for SIDS ... and coastal countries to address their sustainable development challenges' (Abu Dhabi Declaration, January 2014: 1). In sympathetic conceptual closure, a digest on Blue Economy practice authoritatively visions the Blue Economy as it somehow ought to be. Oceans are 'development spaces' where:

spatial planning integrates conservation, sustainable use, oil and mineral wealth extraction, bioprospecting, sustainable energy production and marine transport. The Blue Economy breaks the mould of the ... 'brown' development model where the oceans [are] perceived as [available for] free resource extraction and waste dumping, with costs externalised from economic calculations. The Blue Economy will incorporate ocean values and services into economic modelling and decision- making processes .... [It will provide] a sustainable development framework for developing countries addressing equity in access to, development of and the sharing of benefits from marine resources; offering scope for re-investment in human development and the alleviation of crippling national debt burdens. (UN, 2013: 3)

Such announcements herald beneficial environmental and developmental futures, but the emergence, goals and prospects of the vision are being scrutinized. We thus regard Blue Economy imaginaries as attempts to describe actual, anticipated or promised investment institutional projects, with nameable economic and ecological promoters, beneficiaries and losers. This point of entry reveals the diverse efforts under Blue Economy as actors seek either to rework or to avoid reworking biologicaleconomic relations. It acknowledges 'global' gazing upon international waters but sees this gazing as coming from different vantage points, each with its own geography of locations, knowledge communities, investor circumstances and institutional frameworks. As more 'global' gazes on the oceans are activated from very different geographic positions to the past, it is well to remember that each gaze is interest-constrained, adopts a perspective, is purposive and is never far from being contested by other gazes. There is no innocent global gaze on the oceans, or the planet as a whole. Our immediate concerns in this gaze-etteering are how biologicaleconomic relations are being addressed (if at all), how cognitive hurdles could be veiling or skewing constructive efforts to acknowledge the political and ethical challenges of working in barely understood ocean space, and to gauge the possibilities and 
potentialities that come from rethinking the making of economy-ecology relations. Here, we take pause over Blue Economy optimism, the utilitarian approach to the oceans, coasts and land characteristic of the work being done under this metaphor and the simplified resilience perspective on ecosystems that the discourses share. We also note the initiatives to mandate a strong commercial presence in ocean governance.

Silver et al. (2015) trace the emergence and circulation of Blue Economy through Rio +20 events. The discourses that emerged are not only varied but linked to specific geographic origins and to experiences in particular contexts: they are at odds with each other. They identify four discourses: (1) a 'natural capital' discourse which argues for valuing of ecosystem services as the basis for a Blue Economy; (2) a 'good business' discourse which promotes private sector leadership to overcome 'brown' economy problems; (3) a 'Pacific SIDS' discourse in which new partnerships, agreements and benefit sharing are harnessed to the task of making a more equitable political economy for island states; and (4) a 'small-scale fishers' livelihoods' livelihoods' discourse concerned with human rights and participatory governance issues and seeking to end enclosure of the oceans for industrial fisheries. Furthermore, Silver et al. (2015) establish that conflicting ideas about the expected role of the Blue Economy in development have already emerged among the African Union (it will contribute to development), the Caribbean SIDS (it is not required for development) and Pacific SIDS (it is important for development). While cautioning that much of this usage took place in the context of positioning for negotiations, they argue that multiple articulations emerged and that the term was contested if not protested.

Other voices and initiatives further complicate the scene. Tables 1 and 2 list events relating to Blue Economy that occurred in 2014. When we set aside the summer colleges, conferences and other events associated with Günther Pauli's (2010) decidedly more alternative economic idea of Blue Economy, to focus on those projects associated with oceans, seas and coasts, the Google search, while not exhaustive, revealed 39 events. Table 1 indicates a wide range of sponsors, with differing agendas, mandates, foci and level of activity over the year. Notably, the European Commission (EC) sponsored 21 events in 2014 (Table 2).

We select four EU events to indicate the scope, range, style and cohesion of this activity before summarizing the economic and scientific work on display. The EU's sustainable seas policies provide an identifiable policy framework for this activity, which should be read as evidence of EU investments in research, development, innovation and learning. The absences and the foci of these events speak, we believe, to the general character of the assembly work being done. The four events include a meeting of marine scientists in Rome, a conference on marine spatial planning (MSP) in Venice, a port alliance conference held in Bruges and a meeting of enterprises with potential investors in Liverpool. Each event builds upon years of regional development and European integration efforts, now reassembled under the Blue Economy rubric.

The Rome EurOCEAN 2014 conference was perhaps the largest of these events. It sought to set a 'seas and oceans research agenda for Europe' and contribute a 'Rome Declaration' on research. This declaration's goals covered valuing the ocean, capitalizing on European leadership in marine science and technology, advancing knowledge through ocean observation and fundamental and applied research and breaking barriers to combine expertise from a range of disciplines and stakeholders. Venice staged the fourth conference in a series on MSP, this one featuring presentations related to coastal and maritime tourism. These ranged from reviews of planning for cruise ships in the Adriatic to a call for surfing reserves and the creation of underwater trails in marine protected areas (MPAs). The Bruges seminar explored 'the added value of cross-border working, best practices and key topics for the future' (2 Mers Seas Zeeën, 2014). This meeting signals the fruits of the EU's port alliances, which are meant to feature prominently in the EU's 'smart, sustainable and inclusive' blue growth strategy for 2014-2020 (2 Mers Seas Zeeën, 2014). Cross-border cooperation has developed with support from the European Regional Development Fund, linking port authorities in Calais, Ostend, Zeebrugge, Zeeland, Portsmouth, Ramsgate, Newhaven and Dover. A small- 
Table I. Blue Economy events 2014.

\begin{tabular}{|c|c|c|c|}
\hline Dates & Place & Event & Organizer \\
\hline Jan & Beijing, China & $\begin{array}{l}\text { 12th 5-year development plan for } \\
\text { National Marine Economy }\end{array}$ & China govt \\
\hline Jan 19-20 & Abu Dhabi, UAE & Blue Economy Summit & UN \\
\hline Feb 24-26 & Half Moon Bay, California, USA & 2014 World Ocean Summit & The Economist \\
\hline Mar 18 & Qingdao, China & APEC 3rd OFWG Annual Meeting & APEC \\
\hline Apr 25 & Seaside, California, USA & What is the Blue Economy? & $\begin{array}{l}\text { Monterrey Bay International } \\
\text { Trade Association }\end{array}$ \\
\hline Apr 25 & The Hague, the Netherlands & $\begin{array}{l}\text { Global Oceans Action Summit for Food } \\
\text { Security and Blue Growth }\end{array}$ & $\begin{array}{l}\text { The Netherlands govt, FAO, } \\
\text { World Bank }\end{array}$ \\
\hline Jun 10 & Rome & $\begin{array}{l}\text { Indonesia presents its blue economy } \\
\text { projects at FAO }\end{array}$ & FAO \\
\hline Jul 10 & London & $\begin{array}{l}\text { Financing the transition to a sustainable } \\
\text { blue economy }\end{array}$ & The Prince's Charities \\
\hline Jul I5 & Kingston, Jamaica & $\begin{array}{l}\text { International Seabed Authority (ISBA) } \\
\text { 20th Annual Session }\end{array}$ & ISBA \\
\hline Aug 25 & Xiamen, China & 3rd APEC Blue Economy Forum & APEC \\
\hline Aug 28 & Xiamen, China & $\begin{array}{l}\text { 4th APEC Ocean-related Ministerial } \\
\text { Meeting }\end{array}$ & APEC \\
\hline Sept $1-2$ & Dhaka, Bangladesh & Blue Economy Workshop Bay of Bengal & \\
\hline Sep 03 & Apia, Samoa & UN SIDS conference & UN SIDS \\
\hline Sep 04 & Cork, Ireland & Our Ocean Wealth & Ireland govt \\
\hline Oct 15 & Lisbon & $\begin{array}{l}\text { World Research and Innovation } \\
\text { Congress Oceans }\end{array}$ & UNESCO \\
\hline Oct 28 & Tallinn, Estonia & $\begin{array}{l}\text { Sustainable Development forum 2014: } \\
\text { Blue Economy in the } \\
\text { Vulnerable Baltic Sea }\end{array}$ & Estonia govt \\
\hline Nov $12-13$ & San Diego, USA & 6th Blue Tech \& Blue Economy Summit & $\begin{array}{l}\text { Maritime Alliance } \\
\text { Foundation }\end{array}$ \\
\hline Nov 17 & Barcelona & $\begin{array}{l}\text { 2nd International Ocean Research } \\
\text { Conference }\end{array}$ & $\begin{array}{l}\text { IOC-UNESCO, The } \\
\text { Oceanography Society }\end{array}$ \\
\hline
\end{tabular}

SIDS: Small Island Development States; EU: European Union.

Source: Google search 'Blue Economy 2014'.

and medium-sized enterprises and financiers initiative in Liverpool explored possible projects in offshore energy, ports, shipping and 'other maritime sectors' in the Irish Sea. Speakers came from Barclays Bank, Brabners Stuart, the European Investment Bank; the Irish Sea Maritime Forum; the consultants DG Mare and Poseidon Aquatic Resources Management; Marine South East; the Bibby Line Group; the Port of Cork Company; and Enterprise Europe Network.

These four events reveal that there is, in fact, an identifiable economy, featuring and implying a diversity of investment institution trajectories, with distinctive economy-environment relations.
Estimating all economic activities (except the military) that 'depend on the sea', the EU's Blue Economy is estimated at 5.4 million jobs and a gross value added of just under 500 billion euro per year (EC, 2014a and 2014b). This identification of the Blue Economy is itself a radical departure for economists, since it involves separating out seadependent and related value chains from national economies, identifying a new combination of sectors (blue growth, coastal and marine tourism, shipbuilding and repair, fisheries, aquaculture and transport) and calculating economic performance on the basis of seas. Thus, the Mediterranean Sea accounts for $47.6 \%$ of the EU's Blue Economy 
Table 2. The EU's Blue Economy events 2014.

\begin{tabular}{|c|c|c|}
\hline Dates & Place & Event \\
\hline Jan 14 & Stockholm and Turku & Green technology and alternative fuels in the Baltic Sea Shipping \\
\hline Jan 30 & Budapest & $\begin{array}{l}\text { Sustainable development of the Blue Economy of the Black Sea - enhancing marine and } \\
\text { maritime cooperation }\end{array}$ \\
\hline Feb 06 & Athens & Stakeholder conference on the EU strategy for the Adriatic and lonian region \\
\hline Feb 06 & Brussels & 19th meeting of the Member State Expert group on Integrated Maritime Policy \\
\hline Feb 17 & Brussels & Atlantic strategy: workshop on directly managed funds and operational programmes \\
\hline Mar 17 & Fünchal, Madeira & $\begin{array}{l}\text { Atlantic Action Plan-related growth for outermost regions of the EU and European } \\
\text { territorial cooperation opportunities }\end{array}$ \\
\hline Apr 04 & Brussels & Ocean energy forum workshop \\
\hline Apr 28 & Gijón & Atlantic ports and maritime transport as drivers \\
\hline May 19 & Bremen & European Maritime Day 2014 - innovating for a sustainable use of our oceans \\
\hline Jun 06 & Athens & Conference to explore the benefits of maritime spatial planning for shipping and ports \\
\hline Jun II & Dublin & 2nd workshop of the Ocean Energy forum \\
\hline Jun 13 & Liverpool & The Atlantic Action Plan: finance opportunities for projects, chances for SMEs \\
\hline Jun 30 & Brussels & Re-energizing the oceans \\
\hline Jul 08 & Rome & $\begin{array}{l}\text { Toward an effective European maritime integration: The implementation of the EU } \\
\text { Maritime Security Strategy (EUMSS) and the Common Information Sharing } \\
\text { Environment (CISE) seminar }\end{array}$ \\
\hline Jul 10 & London & Financing the transition to a sustainable blue economy, high level conference \\
\hline Sep 19 & Plymouth & Atlantic Creative Cities gathering \\
\hline Sep 29 & Limassol & Blue Career 2014 \\
\hline Oct 7 & Rome & EurOCEAN 2014 \\
\hline Oct 30 & Port of Augusta, Sicily & Blue Day \\
\hline Nov 06 & Bruges & Small- and medium-sized ports as hubs for smart growth and sustainable conn \\
\hline Nov 27 & Venice & Maritime Spatial Planning conference series: 4 Coastal and Marine Tourism \\
\hline
\end{tabular}

EU: European Union; SME: small- and medium-sized enterprise.

Source: ec.europa.eu/maritimeaffairs/policy/blue_growth/ (accessed 3I August 20I5).

employment and $56 \%$ of value. While the transport sector accounts for $10.5 \%$ of employment but $31.6 \%$ of value, the two largest employment sectors, blue growth and coastal and marine tourism, each make up about one-third of employment but around a quarter of value. Fisheries and aquaculture contribute $14.8 \%$ of employment and $10.7 \%$ of value. Thus, economists have decoupled parts of land-based national economies of the EU to form sea-based regional economies of the EU. This work facilitates the knowing of the Blue Economy, for example, by highlighting the importance of tourism, energy, shipping and ports relative to fishing and by laying the groundwork for measuring the future performance of this economy.

The bioeconomic is not prominently placed in any of this EU activity. The word does, sometimes, feature, as in the Ministry of Fisheries backed international conference 'Growth in Blue Bio-economy,' Törshavn, Faroe Islands, of June 2015. However, since the EU has a separate fisheries agency, since the EC has sets its priorities for blue growth on blue energy, mining, tourism, transport, shipbuilding, aquaculture and biotech rather than capture fisheries, and since MPAs and MSP figure prominently in its methods, the bioeconomic is already framed as either farmed or conserved.

MSP emerged over the last 10 years (Kidd and Ellis, 2012) aided by the EU's embrace of the idea in 2007 (Douvere and Ehler, 2009). The EU aimed to develop MSP as an ecosystem-based planning approach for coastal, sea and ocean management (Ehler and Douvere, 2009). Subsequently, interdisciplinary scientific interest has waxed (Douvere and Ehler, 2001, 2009; Douvere et al., 2007; Drankier, 2012; Flannery and Cinnéide, 2008; Jay, 2012; 
Schaefer and Barale, 2011; Smith et al., 2012; cf. Massey and Rees, 2004). To date, however, studies of marine biology and biodiversity in the context of MSP remain rare (but see Pascual et al., 2011) and constitute a goal for subsequent integration around already developed spatial planning practices for shipping, tourism, energy and so on. Recent assessments call for more critical research into the relation between MSP and its political, social and economic context (Jay et al., 2012; Kidd and Ellis, 2012). Early on, stakeholder engagement was noted as a matter requiring special attention (Flannery and Cinnéide, 2008; Pomeroy and Douvere, 2008), but this attention has tended to be official rather than critical scientific, so that critiques of MSP as a matter of expert capture of ocean management could yet surface. MSP is creating new territories, organizations and realities (Müller, 2015) as well as a new sense of the ocean as social space (Lambert et al., 2006; Peters, 2010), but the emerging territories and organizations come with decidedly neoliberal socionatures, in the senses of Castree and Braun (2001) and Bakker (2010).

However thorough and cohesive these EU policies are, they do not by any means stand alone. The governments of China and Indonesia have been pioneers in charting Blue Economy policies (Liu, 2011; Tam, 2015), Bangladesh and the Seychelles are active (Chatham House, 2014; Shahneaz and Salma, 2015) and India is waking up to the challenges (Sakhuya, 2014). At the regional level, Asia-Pacific Economic Cooperation (APEC) has formed working groups and the SIDS has held a series of meetings, the most prominent of these in Apia. President Obama has declared large new MPAs. There will be mounting expectations from the UN on member states to bring management of their exclusive economic zones (EEZs) into line with international best practice, now being set in China, Indonesia and the EU, and now attuned to Blue Economy initiatives.

A range of other agencies and actors, including scientists, can be identified working under the auspices of Blue Economy, with each actor looking to dovetail their specific work into policies like those of the EU. Take for instance the World Ocean Council. Claiming 70 members and a readership of 34,000 , the Council was set up to promote "corporate ocean responsibility'. Dedicated to 'ensuring that ocean industries are well informed of the ocean policy and planning processes affecting their future operations and well equipped to make decisions on whether and how to most effectively engage in these developments', it cultivates commercial perspectives on governance challenges in select venues (World Ocean Council, 2014). Based in Honolulu, the Council ran an 'Our Oceans Challenge' in 2014 in which entrepreneurs were invited to address the need for port reception facilities; to minimize the impacts of marine sound or sedimentation from construction, dredging, mining or industry operations; or to optimize the use of vessels and structures for collecting ocean data. This agenda suggests an awareness of collective impacts from specific operations, and certainly anticipates increased investment in the Blue Economy.

In recent, prominent exercises, designed to identify the most important questions in oceans management, scientific groups including natural and social scientists did not use the term Blue Economy at all. In their priority-setting exercise for Canadian ocean science, Fissel et al. (2012) use 'global change' to frame economic as well as climate change processes and acknowledge ocean-based contributions to the economy in terms of employment, trade and GDP. But their questions are pitched at appraising alternative governance systems in terms of their inclusion of First Nations peoples, at identifying appropriate research, information and tools, and especially environmental and social impacts, risks and benefits of human activities under the goal of sustainable ocean management. Their report is adamant that social scientists and social knowledge will be required. Indeed, economic appraisals of human impacts on the environment or of ecosystem services are not presented as issues for sustainable ocean management. This stands in contrast to the 2014 Rome Declaration discussed above which is premised on an already formed EU blue growth initiative.

Parsons et al. (2014) consider conservation of marine biodiversity by highlighting the degradation of marine ecosystems in the contexts of the Anthropocene and the marine environments' ecosystem services. Their list of questions, consolidated 
through a series of workshops in 2011 and 2012, should be troubling for anyone promoting a Blue Economy agenda, not only because it, like Fissel et al. (2012), acknowledges fundamental concerns over the state of research on the oceans but because it raises serious bioeconomic challenges. Particularly troubling to us are the questions 'how can the cumulative effects of the use of new technologies (e.g., energy infrastructure) be rapidly and effectively assessed and translated into precautionary policy recommendations?' and 'how should damage from anthropogenic oil release be quantified and what is the ecologically relevant scale for assessment?' These speak to the absence of agreed practices that will be necessary for an integrated marine planning of the kind proposed in the EC's Blue Economy agenda. Their questions constitute a chilling reminder of the state of unpreparedness of conservation science for the challenges of the Blue Economy and chime with Lubchenco's warning that 'We don't want the blue revolution to repeat the mistakes of the green revolution... It's too important to get it wrong, and there are so many ways to get it wrong' (Lubchenco cited in Simpson, 2011: 61).

Furthermore, we note that Blue Economy initiatives have emerged at a specific conjuncture. The problematization of both earth ecology and the western development model by the ideas of the Anthropocene, planetary boundaries and tipping points (Crutzen and Stoermer, 2000; Rockstrom et al., 2009), combined with major shifts in geoeconomic, political, social and cultural interest in and understandings of the world's oceans (Agnew, 2009; Dalby, 2009; Sparke, 2013), give new urgency to reassessing nature and economy and is forcing renegotiation of biological-economic relations connected with ocean activities worldwide. The Blue Economy proposition spotlights governance in the ocean, in a moment when American hegemony on the seas, backed by an open seas policy, is being challenged by governments and nongovernmental organization (NGO) actors operating in the ocean. The Abu Dhabi declaration, for instance, joins the new geopolitics of the polar regions, the international law of the sea, extensions of EEZs and the presence of competing surveillance systems. To these pressures can be added monitoring of Southern Ocean whaling, action against piracy off the shores of Somalia, the blockade of the Persian Gulf, efforts to control and stem the migration across the Mediterranean into Europe, and the contests, in the South China and East China Seas among many other places, over oil exploration and drilling rights.

Therefore, we must be careful to understand how Blue Economy is conceived and positioned conceptually. There are competing foundation stories and views about what 'blue', 'economy' and Blue Economy mean, and these may not intersect with the anxiousness of the times. A curious feature of Blue Economy is the sense of surety conveyed by the word 'economy', which is presumed to be positively transformed by new relations that are somehow invoked by 'blue' inspiration. Blue Economy thinking is deeply entangled, although not always explicitly, with views and assumptions about existing biological-economic relations, and is often enlivened by perceived opportunities to redress and develop afresh the content of these relations. Where the Anthropocene and planetary boundaries understandings profoundly alter how context must be imagined, Blue Economy initiatives raise questions about how investment, regulation and governance might be thought about. In turn, this exposes the framing of relations between biological and economic processes and the efforts under this framing to harness and legitimize investment into 'frontier' developments in coasts, seas and oceans.

\section{Mobilising geographic knowledge}

Geographers have built specialist awareness of the geoeconomic, political, cultural and social developments in the 21 st century, and this awareness can be used to understand Blue Economy ventures and how Blue Economy imaginings are being enrolled in governmental plays originating from private, public and other quarters. By inquiring into both material and discursive trajectories of investment and institutional arrangements (Fagan and Le Heron, 1994; Le Heron, 2013), geographers can demonstrate that existing and emergent configurations of investment and institutions are part of how Blue Economy 
might be narrated (Allan, 2012). Major insights are accruing from recent geographical work on territorialization (Bear, 2012; Brenner, 1999; Elden, 2010; Klauser, 2012; St. Martin, 2010) which transcends the container nature of national frameworks. This thinking is now multifaceted. It embraces multiscaled connections, networks and relations of agency in space that are constituted by and constitutive of geographical patterns of organization. Simultaneously, it focuses on new processes and dynamics changing these within and across spatial contexts and the likely mutualities of deterritorialization and reterritorialization that result. Finally, specific processes of upscaling, downscaling and outscaling $(\mathrm{Nel}, 2014)$ are seen as features of reconfiguring frameworks and narratives.

Until very recently, it has been very difficult to comprehend or visualize emerging territorializations in oceans and coastal waters (Steinberg and Peters, 2015). It is difficult to compile bigger picture overviews of investment and institutional dynamics centred on actors beyond fisheries let alone within them. From a socioecological perspective, we are equally cognizant of the excessive claims made about the sustainability of fisheries' biologicaleconomic relations, especially when mounting evidence indicates the biological-economic model of fisheries management using fish stock assessment and individual transferable quota (ITQ) frameworks depends on a host of exclusions, such as ecosystems, communities and labour relations, in calculations of economic and sustainability performance (Winder, 2017). The post-human turn in geography points to limited engagement with both the biological and biological-economic relations, in most of the socioecological literature (Le Heron et al., 2016a, 2016b). Our view is that the Blue Economy should be of interest to those geographers whose interests do not (currently) extend to fisheries (or even seas) or the emergent geographies of scientific knowledge.

A considerable wealth of recent geographical work can thus be turned to the task of understanding Blue Economy and the biological-economic analytics and reframings associated with it. Conservation biologists have picked up on ocean citizenship (Fletcher and Potts, 2007) as a framework for engaging a concerned public, and there are extensive efforts to map the effects of human impacts on marine ecosystems (Halpern et al., 2008). Our engagement is designed to explore the differing ontological, epistemic and methodological bases that are Blue Economy in the making. To this purpose, we enlist specific geography literatures. We draw upon recent advances in post-structural political economy with its emphasis on revealing structural and agentic processes in both investment and institutional trajectories (Lewis et al., 2016). We acknowledge recent assemblage literature that prioritizes probing conditions of possibility and the impacts of conceptual restriction in contextual settings (Allen, 2012; Anderson et al., 2012; Anderson and McFarlane, 2011). We also enlist efforts in the construction of socioecological knowledge which re-explore human and more than human intra-actions (Le Heron et al., 2016a, 2016b). Our main concern, here, is to augment the political economy approaches that have marked geographers' vanguard studies of Blue Economy by mobilizing investment institutional, socioecological and assemblage approaches.

\section{Assembling an approach}

We ask: How might the assemblage literature be deployed to inquire into phenomena such as Blue Economy imagining and the co-crafting of biological-economic relations? Our introduction juxtaposed individually definable yet heterogeneous investment institutional initiatives of quasi collective shape that we contend can be productively explored for their biological-economic features and differences, possible directionality, inter-subjectivities and transitions in key practices and for their disparate and accumulating influences on collective behaviour and thinking. Although the term 'Blue Economy' is traceable to books like Pauli (2010) and Kim and Mauborgne (2005), outlining, respectively, principles and advice to individual businesses, and a notion of creating and capturing 'blue oceans' of uncontested market space through disruptive innovation, the variety of collectively harnessed marine imagining displayed globally, clearly suggests a research problematic that 
demands knowledge approaches able to accommodate both spontaneous interrelation and hybridity as well as orchestrated developments. This we see as crucial to our interpretation that the Blue Economy should be viewed as an agentic-centred, expanding and mutedly contested globalizing constellation of actors, investors, imaginaries, officials, multiple spheres of economy and culture, small and large biota, presumed organisational practices, geographic scaling, governable spaces and governmental technologies. The ontological openness of this view gives conceptual space to explore the diversity of assembling activity, and this we contend is how fresh insights into the making of biologicaleconomic relations can be obtained.

In seeking to reveal Blue Economy assembling, it will not be sufficient to analyse the imagining as typified by existing experiments and discourses. Many projects are still being imagined, have been formulated but have not been understood as part of ocean activities and so on. Therefore, in addition, we must contemplate research into a plurality of (potentially multiplying) phenomenon, often previously unrelated, but now being bound together through many and varied investment institutional initiatives. In these, potentially new biologicaleconomic relations are being forged. We know little about this emerging field. These qualities expose formidable cognitive challenges for researchers and necessitate extensions to assembling thinking.

First, there is a temptation to assume too much clarity from a descriptive overview such as we have already provided, when the range of declaration points about Blue Economy available to researchers is at best slices into probably volatile and poorly associated trajectories, whose relational features and status can only be characterised (loosely) through empirics. There is the risk then of attempting to find common elements by aggregating from instances as traditional science would encourage. Instead, we can seek to avoid this totalising trap by revealing from situated studies the nature of scaled and fluid articulations that define each initiative.

Second, our contention that geographers might be intellectually and practically active in Blue Economy making means we are seeking, like Simon and
Randalls (2016), to engage in specific sites and struggles, rather than confining our focus to definitions, detached descriptions and management formulae. The common thread in Blue Economy making comes from the inevitability of consciously or unconsciously defining biological-economic relations, for particular ontological and epistemic tents of diverse Blue Economy activities.

Not only are the initiatives likely to exhibit features of difference that spring from their emergence, this constitutive multiplicity is itself open to multiple interpretive framings. It is for this reason that we distinguish between (1) the declarations about Blue Economy that are in the public domain and which researchers can access in various ways, (2) points of entry from disciplinary positions where questions of concern may differ, (3) institutional formations with diverging policy positions and (4) commercial initiatives guided by business models.

Fourth, while the geographic literature is attentive to the fundamental link between imaginaries, places and practices (Baragwanath and Lewis, 2014; Kobayashi, 2009; Silvey and Rankin, 2011), this aspect requires major shifts in methodology towards naming actors and their inevitably reviewable but mutable values and practices. This is a strategy to spotlight human and nonhuman beneficiaries, losers and the nature of collective and cumulative impacts.

Any immediate search for common elements is likely to be an unwitting commitment to use existing categories of description and explanation. An artificial kind of general emergence is being constructed when apparently common features are privileged early. In order to deal with this ontological veiling of both investigation and interpretation, we draw on the methodological experimentation of Clarke (2003), Le Heron et al. (2013) and Reilly (2015), to leapfrog the predisposition to use existing categories in inquiry and to open up new and contemporary conceptions.

A burgeoning grey literature, especially generated by environmental NGOs, community groups and indigenous people (Coombes et al., 2004), offers interpretive anchors that are both panoptic in character from their presence in many settings and practice critical, because of the range of 
exposure they meet. That said, this is often accompanied by a form of historicism that strings together a sequence from, for example, brown to green to blue economy in spite of attempting to prioritise sufficiency over scarcity (McAfee, 2014). Our methodology avoids using conventional orderings. Instead, it allows for independence in assembling knowledge, in and for different settings.

Finally, we seek to develop clearer situated and wider understandings of material structures, agency, practices and discourses shaping the terra incognita of how the biological-economic is instituted and stabilized into solutions. In this, we follow Bailey and Caprotti (2014: 1810) who in their green economy analysis resist trying to decide on whether the green economy represents the 'engineering of a conflict-free politics of transition through the consolidation of a unifying vision' or, instead, because of its multidimensionality, provides 'fertile new arenas for debate about socio-economic futures'.

We are also motivated in our privileging of biological-economic relations by insights obtained from longitudinal work among humanities and social science researchers on the ITQ system of market-based environmental governance. Confronted with the Blue Economy, we were at first inclined to simply reassign fisheries into Blue Economy conceptions, but there are lessons for assemblying from recent critical work on a quarter century of ITQ experimentation in fisheries that we think should be highlighted in any attempt to map and understand Blue Economy.

First, the QMS-ITQ is not only an infrastructural platform of expertise and knowledge allying diverse actors but is also an investment institutional framework which has a constant companion - a particular freezing of biological and economic relations into a standardized model. It can be used in any EEZ, is the preferred management method, ties into new technologies, and fits national development projects and modernisation initiatives (Hamilton-Hart and Stringer, 2015). The actors in this alliance reinforce the choice of the model and promote the model's performance among different constituencies. Regulation and governance are an inseparable part of the project. However, Bromley (2011: 290) has argued from his analysis of the contradictions and 'impossibilities of claims' (Fletcher, 2013) that in the fisheries world there has been 'systematic detuning of national governments and fisheries management agencies into believing that management is "virtually unnecessary in an IFQ fishery" [individual fishing quota] (emphasis added). This view warns that the model came to stand in place of management, and that management has been demoted or relegated to the sidelines, while government acts on new opportunities: after all the fisheries problems are in hand.

While ITQ is performance oriented, it is obvious from both internal and external critique that it has been performing inside expectations and unpredictably and disruptively (Winder, 2017). The interests of traditional, local and inshore fishers are expendable under this approach, and so are wild fish. In this last case, the Blue/Brown Economy dichotomy can be used to selectively represent past failures (Brown) and relate them to the promises (Penders and Goven, 2010) of more efficient, modernizing practices (e.g. the Blue Revolution) which, it is assumed, will deliver better bioeconomic outcomes than the old styles of modernization.

While new goals and practices continue to appear, such as resilience, risk modelling, MPAs and MSP (Bear, 2012; Lockie, 2014), the methods used to (reliably and scientifically) know how many fish there are have not been replaced, as is revealed by the use of (sustainable yield) stock numbers to legitimate Blue Economy initiatives in the $\mathrm{Abu}$ Dhabi declaration. This persistence is remarkable, and, since the fisheries bioeconomic model is based on very limited ecosystem understanding, it will be a challenge for this model to interact with the emerging new practices. However, it is also not the same bioeconomy model with which the ITQ experiment started. The constituent group of economists and biologists associated with the bioeconomic projects of different countries is being steadily recomposed. These features are of utmost importance in grasping what some of the challenges of the Blue Economy are likely to be and sound a warning: actors in the current Blue Economy 'assemblages' may already be slipping into existing tendencies including limited attention to management, enrolment of business, expendability of traditional fishers and wild 
species, reliance on old bioeconomic models and generation of standalone scientific models and constituencies that do not interact with each other. How well prepared are different knowledge and emerging policy and management communities for 'crossassemblage' engagement that will spring inevitably from the expansionary impulses of each 'assemblage' of investment and institutions working in the same spaces and amongst 'development spaces'?

We now turn to two contrasting empirical interventions. Our first move is to compile investment institutional initiatives into a 'conceptual mapping' of the many existent and longstanding instances of ocean, coast and land-related economy. Our radical collation does the methodological work of splintering an under-known domain into many activities, the ontological work of probing the different kinds of value-means-ends propositions that shape activities and the epistemological work of questioning the actual or implied nature of biologicaleconomic settlements. We cannot over emphasize that the identified initiatives are about investments and institutions in combination and organized for the most part to achieve conventional economic growth. But, as we argue, there are differing kinds of growth that could be performed into existence in the current conditions. Our second intervention considers efforts being made in New Zealand to make and grow the marine economy differently. Here, we can see an enactive approach at work, one embedded in emerging participatory processes, which seeks the co-assembly of new economic practices and qualities (Bridge, 2011; Li, 2014) that create new value possibilities in multi-use environments.

\section{A relational conception of Blue Economy}

While ocean is being remapped through imaginaries about its potential as an investment space, the Blue Economy in its manifold forms of imagining is compartmentalized, unsystematic and even contradictory in intent and organisation. When empirically and critically scrutinized, it embraces far more than the ocean and fisheries and involves investment institutional initiatives predicated on largely unrevealed assumptions about biological-economic relations pertaining to sea, coast and land (Winder and Le Heron, 2015). Therefore, here, we outline an approach that will identify the knowledge scapes being assembled. It is the aim of Blue Economy to identify links and possibilities between the economic and ecological so as to stimulate new forms of economic behaviour within biological processes and to facilitate opportunities to deliver sustainable collective and individual benefits from oceans.

Figure 1 co-locates an array of activities, without reference to disciplines, fields of research or institutional advocacy, that are referred to in the Blue Economy discourses we have been reading. The figure assembles but does not try to prioritize or organize these activities, and thus breaks with prior conceptions and assumptions of what might make a research object. Instead, the figure invokes relations in the making. Each investment institutional initiative under Blue Economy will assemble actors around a specific combination of these with competing visions of what to do with imagined development spaces. We contend the actors may be inward looking, reluctant to acknowledge multiple presences, could be blinkered to what might be going on in other 'assemblages' and have little sense of wider implications of what they are doing or others might be doing that could be of consequence to them (Cohen and Bakker, 2014). Were a similar figure created for each country, scientific community, industry, local community and policy unit conventionally associated with ocean, coast or land to show Blue Economy activities for each specific jurisdiction, they would differ, though overlaps would be found, and it would be difficult to exclude land- and shore-based activities from the inventory, and the extent and diversity of the lists would probably surprise.

This conceptual framing meshes neatly with the idea of SIDS building negotiating positions as they discussed Blue Economy in UN contexts (Silver et al., 2015), but our approach goes further. Blue Economy both introduces and reproduces compositional diversity and conceptual fluidity, and thus serves both as a schematic that is open to fresh inputs and learning at different geographical scales, and serves as a reminder that each activity is likely to be co-constituted through particular and contested biological-economic relations. A striking 


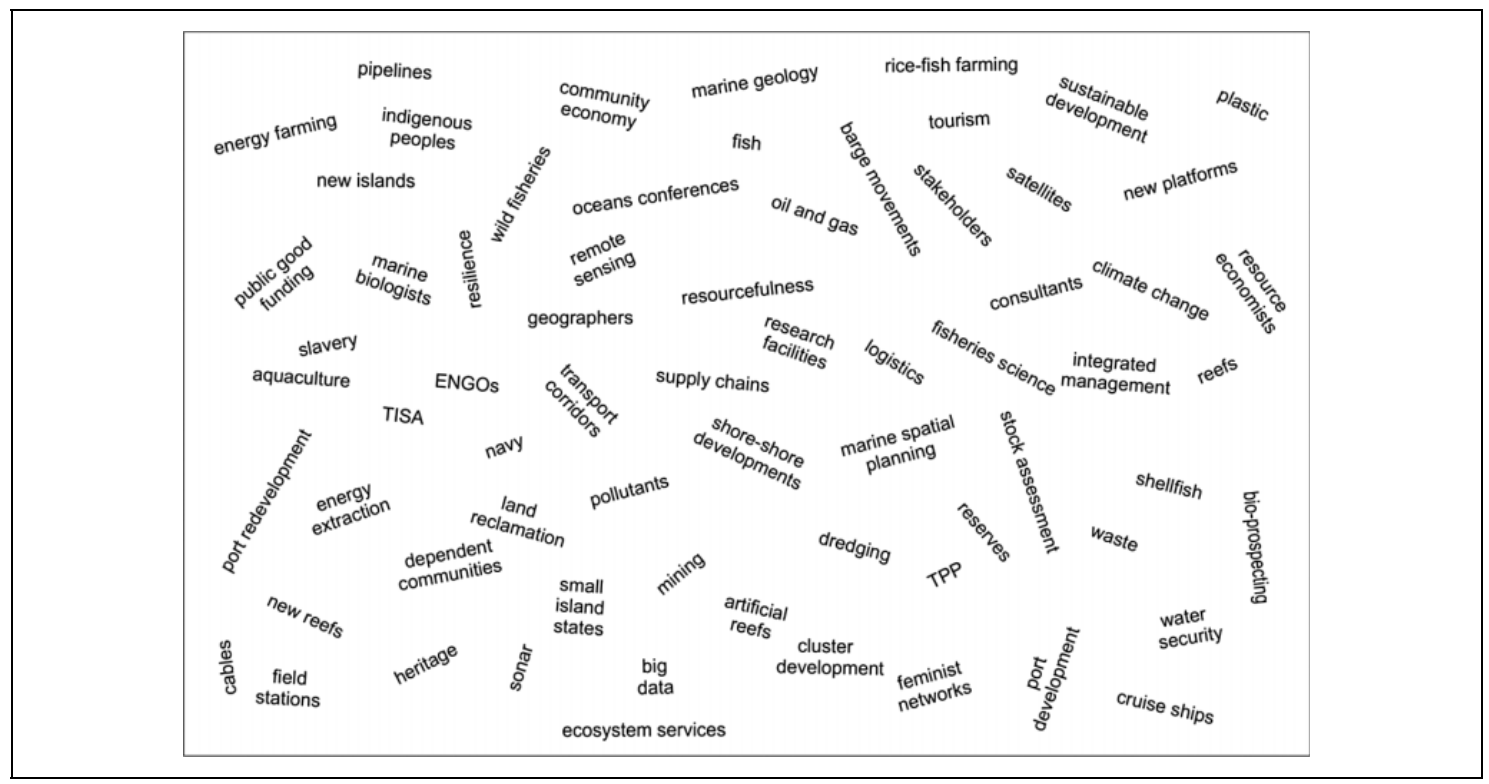

Figure I. The Blue Economy as investment institutional assemblage.

point of our visualization of the activities of Blue Economy (Figure 1) is therefore that the likelihood of collision in geographic and environmental contexts can be 'seen' by virtue of bringing these activities together on one page. Although premised on the idea that everything (especially economic and environmental relations) is alike, must look alike and can be handled alike, the figure reaches beyond this idea to acknowledge the need to accommodate difference within Blue Economy. Anyone working with the ontological substrate of Blue Economy will have to discover and pursue not only issues but also good practices. We envisage working with unalike and alike initiatives and their values-means-ends trajectories in the same marine space, and therefore see Blue Economy as a call to heighten collaboration, not so much to resolve differences as to create new solutions out of a proliferation of knowledgerich engagements. In this regard, Blue Economy imaginings can be seen as potentially rules or makeable governmentalities (Larner and Le Heron, 2002) on how to proceed in context, instead of an imaginary of pre-existing or pre-determined orderings and procedure applicable everywhere.

We regard each Blue Economy initiative as experimental in so far as each initiative is likely to feature selections from a number of possible biological-economic arrangements. This stresses the unmet and unmade dimensions in every case. Thus, the Blue Economy challenges the adequacy of existing conceptual mappings and the assumptions behind these. The schematic, for example, does not divide the Blue Economy world by 16 $\mathrm{km}$ or 200 mile zones. This holds for fishing as much as for other activities. Equally it avoids over privileging deep sea fishing, since this must now sit alongside planning for oil prospecting, MPAs and so on, and not simply be regulated separately. Similarly, aquaculture can be critically examined in the context of newly recognised and wider relationalities. Underwater infrastructure is brought into the figure, imputing a 3-D quality (Solnit and Snedeker, 2012; Steinberg and Peters, 2015). There is an undeniable ocean-coast-land territorial situatedness to every activity, and every perspective, and narrative on activities. The figure evokes the potential of cross and within assemblage geographic scalings, replete with flows of technologies, materials and the legal and technical apparatus of measuring and controlling relations (Elden, 2010). These are likely to be 'zones of awkward engagement' (Tsing, 2005) involving 'reorganization of the politics of scale and 
networks' (Bulkeley, 2005). Water is the connective tissue around biological-economic relations in spite of conceptual relegation of inland waters, waterways and constructed water holding installations from many Blue Economy accounts. It is a conceptual mistake to restrict the framing to oceans and coasts alone (Le Heron et al., 2014; Steinberg and Peters, 2015). There is a need to be alert to distortions in scientific, public, commercial and governmental imaginations that arise from ignoring the complexities of relations that are now emerging, but whose significance is multiple and highly contingent.

The figure forces the reader to question how we conceive of space and time and how these are organized in scalar frameworks (Cook et al., 2015: 235). It invites discussion of feedbacks, vulnerabilities, perspectives, attitudes, expertise, thresholds and resilience and, conceptually, prompts methodological and epistemological investigation of ways of knowing and governing. A heterogeneity of knowledge-government relations might be mapped into visibility. Different horizons of collective challenges become knowable. How we co-learn in this variety becomes a central issue. The comparative work is just beginning, but initial associations suggest unusual and unexpected combinations in marine spaces. At present, there are almost no stories circulating about choices being made, how they are being dealt with, the nature of commitments being made, or what trajectories or consequences from choices are beginning to look like.

Many assembling initiatives are possible under the Blue Economy and yet these must be placed in dialogue with each other, and this is perhaps the challenge ahead. MSP must be a focus of geographic enquiry: is it up to the tasks being expected of it? Blue Economy imagining must help society and international and national investors to navigate economic-environment relations specific to each context and provide more guidance on directions developments could take. Business leaders have been imaginative and constructively assertive in naming possible relations and exploring their mutual existence in ways that are barely perceived by most people. Perhaps, the Abu Dhabi declaration is a sign of a rush to include unrevealed 'assemblages' as well as to be 'officially' included in the making of something perceived to be new. Nonetheless, each 'assemblage' in one form or another is becoming the object of knowledgemaking attention aimed at finding solutions to pressing issues in multi-use marine space such as keeping individual while creating collective economic and ecological benefits, or developing tools for investors and resource managers that trace the dynamics and cumulative effects of regulation, governance models, social values and consumer behaviours across scales. This will involve confronting the knowledge-expertise-power relations that create conditions for different possibilities of territorially transformative capabilities of individuals and groups acting in relations with each other in their environment (Allen, 2012; Le Heron et al., 2016; Lewis et al., 2016; Rosin et al., 2013). This line of investigation is increasingly being adopted in order to shatter abstract debate and the influence of established interests. In practical terms, however, there is much to do, not the least being theorising socioeconomic objects for co-governance and co-developing and trialling new protocols in different settings.

\section{Assembling a Blue Economy initiative}

The project called 'Making and Stewarding a Blue Economy for Sustainable Seas' is an integral part of the Business and Research Plan of a New Zealand National Science Challenge (NSC). Richard Le Heron was directly involved in developing this initiative, which we treat as an emergent, enactive Blue Economy initiative, and discuss in order to illustrate our approach and the issues emerging. We begin by noting aspects of context, contingency and circumstance pertinent to a grounded discussion of this geographically informed Blue Economy project proposal.

New Zealand's marine realities and knowledge scape have become highly politicised since the 2000s. In this milieu, economy and ecology have been gradually tutored into new conceptual associations. The Blue Economy idea has figured in this momentum. The Royal Society of New Zealand's (RSNZ, 2012) scientist-led review of marine issues benchmarked the new complexities. It reassessed 
New Zealand's marine estate in EEZ and international custodial terms using a New Zealand-centred map, but this achievement was offset by a series of omissions. The contest over the demarcation of fishing grounds or marine reserves was omitted, and instead, responsible use of marine space was represented only by a mapping of trawl tracks and drilling operations. Māori demands for inclusion of their rights to kaitiakitanga (stewardship) of marine resources were ignored, as was the impact of the Hauraki Gulf Mārine Park Act 2000 which established a new conservation estate within the Auckland metropolitan region's already contested regional coastal zones. Furthermore, it failed to signal marine water quality issues as important, despite growing evidence of land-based runoff from farms into waterways and coastal waters, a matter of landcoast-ocean interdependencies subsequently highlighted by the Parliamentary Commissioner for Environment (2013).

By the mid-2010s, New Zealand was thinking of its large EEZ in terms of a multi-use marine space, where the notion of ecosystem-based management (EBM) was increasingly seen as desirable, and the 'extractive worth' of the marine estate was widely talked about. An unprecedented structural intervention in science funding, through an NSC process started in 2013, and directed New Zealand science to the mission of 'growing the economy' through the mechanism of additionality from doing science differently. Specifically, the process included 'Vision Matauranga', an effort to produce an institutionalised template of Maori development aspirations that could be referred to in decisions about growth, and other efforts to incorporate social science knowledge. Furthermore, the traditional landbased view of economy was expanded to the marine, through a separate Sustainable Seas NSC (SSNSC). Blue Economy imagining was advanced by thinking economy differently with the accent on its construction or making.

Encouraged by a decade of collaboration with ecologists around socioecological knowledge, a group of New Zealand human geographers joined marine centred teams bidding for national research money under the SSNSC call. In these efforts, they were positioned in both supportive and leadership roles, asking critical questions, while trying to reframe the direction and focus of research agendas. When the SSNSC process began, 'economy' was taken for granted, a noncategory, unworthy of social-scientific attention. There was neither an initial plan to promote Blue Economy nor was it a foregone conclusion as it became clearer that the idea would gain currency. Initially, Blue Economy was a proto concept that was criticized (it is not science), but it became an object for further study as it offered a vehicle to link economy to ecology and EBM developments. From the outset, two targets of engagement were prioritized as strategic knowledge interventions that were different: (1) linking social and ecological processes in framings that exceeded a science view of a need to quantify social impacts and (2) restorying economy as economic practices that always are embedded in ecological conditions ahead of being knowable from national data sets. By seeking to invent and implement the new (so picking up on 'additionality') rather than peeling away layers of a phenomenon's 'invisible' properties so as to achieve better understanding, the human geographers sought to be proactive in ways that went beyond Wacquant's (2015) ideal of enactive ethnography. They judged that converging knowledge trajectories in New Zealand and shifts in cognition would open up a space for greater geographic and social science engagement and the grounds for this judgement deserve some explanation, since from them more can be learned about the potential for geographers to engage with Blue Economy.

So far the Blue Economy idea in New Zealand has surfaced from two knowledge trajectories: Maori development (Bargh, 2014) and economic geography. Bargh (2014: 467) comments that:

The Blue Economy comes from a particular cultural genealogy. While there is some reference to Indigenous peoples, it does not consider how to build on practices that have been used traditionally and which may support the Blue Economy ideals.... This focus on relationships between people and the land is not something that has been considered by Pauli or factored into considering how and why people and therefore enterprises are motivated to act. 
That Bargh notes this limitation to Günther Pauli's alternative economic approach should be read as a sign of Maori claims to rights within the economy and of the sophistication of Maori critiques of regular growth politics in New Zealand: even alternative growth strategies from outside New Zealand are not adequate to the task of accommodating indigenous community aspirations.

The economic geographers brought expertise in enacting or making economy, a disposition that presupposed being engaged in and with stakeholders. This capability had been developed in the landbased sector (Lewis et al., 2013; Le Heron et al., 2016), further extended in the 'Marine Futures' project (Le Heron et al., 2016b) and explicitly refashioned for SSNSC purposes.

A significant challenge of the SSNSC has been recognizing the pluralities of conception, multiple uses and differentiated value bases and their accompanying knowledges and practices at work in marine areas. Why so? Conceptually, how framing is done, matters. New Zealand lacks a tradition of looking for plurality. Early portrayals of the marine economy as part of the Centres of Research Excellence Fund assessment process were terrestrial look-alike, filling out a list of activities ordinarily missing, without elaborating how the marine economy could be different (Le Heron, 2014). ${ }^{1}$ Recognizing that marine spaces, whatever their territorial scale, do feature multiple uses, does not immediately mean that the legitimacy of different uses is accepted or that they are seen as commensurate. Because each use entails biological-economic arrangements, new knowledge is vital to deal with their co-emergence and complexities. The jump from the interpretive frame of such an established and highly visible activity as fishing, to the knowledge needed to explore multi-use (e.g. of fishing, aquaculture, tourism and oil exploration) is a big step, and one that cannot be made through yet another call by scientists for aid for their particular activities and interests.

On the other hand, joining ecology and economy is not automatic either. On a number of occasions, scientists were reluctant to take seriously stakeholders in research processes and knowledge production. It was difficult, for instance, to get across that the co-production model means that the start-up line needs to have the full complement of relevant parties. In another situation, vehement stakeholder reaction occurred after a lengthy briefing to diverse stakeholders, covering only the economic potential of different parts of New Zealand's EEZ, without companion mention of the ecological concerns for each area.

One whale in the conceptual aquarium of economy-ecology relations is made up of the legacy, immediate agency and prospective behaviour of those in New Zealand's fisheries complex. These stakeholders show a shared confidence perhaps conferred by the ITQ system which gave a social licence unobstructed by other marine users albeit to operate within a tight governance process. Revealed behaviour of the industry and related governmental arms in a number of multi-use environments (e.g. the Hauraki Gulf Forum and Auckland Council's Sea Change process) points to disinclination to engage in developing multi-use processes and selective storying of the industry's sustainability achievements. According to Le Heron (2015), at the 2014 seafood industry conference, billed as 'Growing the Blue Economy', 'there was absolutely no discussion about what a "Blue Economy" might be or might look like in any aspirational or even prosaic terms. It seemed taken for granted that the Blue Economy was simply a seafood industry (emphasis in original)'. Furthermore, 'there was a sense that they feel their practices are fine (emphasis in original), that for example the quota management system (QMS) system protects them and allows them to feel comfortable that they are doing the right thing. This contrasts to the open attitude of the mining and oil sector interests, who regularly attend and contribute their insights and suggestions', rather in keeping with those identified earlier in the article.

Another 'whale' is that much marine science assumes change can be managed or regulated into existence through policy, a view that has encouraged a reluctance to connect with investors, their decision-making and choices, while holding that the insights of science would suffice once in the hands of policymakers. From this conceptual box, social science could only assist with changing behaviours to align with policy or provide social impact analyses. When EBM is coupled with economy, scientists 
are forced to step outside of the usual frames of reference in marine resource management. Accumulating research indicates that major barriers of perception, attitude, motivation, responsibility, accountability and commitment get in the way of the uptake of new thinking and practices. Brown et al. (2010) argue that despite a range of positions most people inhabit in their professional and personal lives, when they consider how they know, they typically favour only one knowledge domain, ignoring the rest. This is in part why new knowledge is often found to be uncomfortable (Rayner, 2012), as it questions existing ways of comprehending problems. The intellectual climate is changing, attesting to ongoing re-framing of science questions and exposure of assumptions, through the lens of social, political, cultural and economic knowledge.

New Zealand science is slowly and unevenly acknowledging that how knowledge is produced has to be taken seriously, a necessary step before pinpointing what questions to ask. This new emphasis has spawned two remarkable changes in research practice. First, in New Zealand marine and other spaces, Maori have been insistent for many years that economic development must comprise genuine partnerships that acknowledge Maori rights to stewardship and ownership under the Treaty of Waitangi, New Zealand's foundational document. This different conception is powered by now deeply institutionalized and sizeable research capabilities, which are actively aligned with central and regional government, the science sector, industry and community processes. Maori aspirations add extra dimensions to plurality in New Zealand economic development: This is not simply a matter of 'participation'. Unique articulations are resulting. For example, the Ministry of Business, Innovation and Employment requires co-development of research steps within any response to its research calls. Novel engagements are underway. Application of the Vision Matauranga involves processes dedicated to sharing understandings, negotiating to discuss possible shared understandings and committing to respectful use of new joint insights and approaches. These developments mean much backstopping of steps forward, and it is harder to slip back to old norms of 'detached', nonparticipatory research.
Second, New Zealand is witnessing an explosion in participatory processes, prompted in part by the NSC process itself, but more widely by glacial progress in completing planning reviews, and protracted decision-making processes for applications for investment approval, a number of these, King Salmon (aquaculture), Trans-Tasman Resources (mining) and Chatham Rock Phosphate (mining), being in marine multi-use spaces. Science and the NSC process are caught between (1) the fact that many central government departments are reviewing their approaches to regulation and policy processes, while (2) in the case of regional government, new participatory models are being trialled, complicating the goals and effects particular participatory processes might have. The stated intention is to give investors better procedures wherein they can scan consent and other processes to determine whether they have assembled adequate evidence before going ahead with an application. In addition, the shifting capacities to engage and spotlight different value systems had two major impacts. First, participatory processes are eroding the premise that science knowledge is something to be discovered and made available by scientists, and replacing it with a view that unless relevant 'stakeholders' with Maori in partnership, are involved, from the beginning, in newly designed-for-purpose collaborative processes, business as usual would prevail. Second, the 'what are' or ontologies of actual economy making that are being discussed are actually often being 'seen' by others, but, in the first instance, outside the SSNSC process.

To summarize this experience of emergent assembling, what transformed into a Blue Economy research initiative was unashamedly a geographic intervention that has always been (and continues to be) a conditional knowledge proposition, about running experiments in making economy. Unexpected alignments are producing remarkably new investment and institutional conditions in New Zealand's marine space and altering perceptions of what is possible, permissible and pertinent. The initiative emphasises the gains from transparent processes that are accruing from stabilising knowledge and interest politics into negotiated arrangements, because 'safer' conditions of participation 
catalyse innovative approaches to problem conception, regulatory input, practice development and so on.

A group of human geographers grasped enough of wider developments in New Zealand and the SSNSC context to be able to assemble their own theoretical propositions about economy making into a Blue Economy research narrative that might do new societal work on behalf of sustainable seas. In this, they had begun to reset how economy and ecology (as EBM) could be approached, by targeting 'new economic practices that work in the dynamics of particular marine environments' (Lewis, 2015). Economic practices are the main mechanisms by which new economic and social values are created to sustain and enhance the resourcefulness of marine spaces. The approach therefore mobilizes new economic and social practices by seeing the value and practice worlds of multiple users, using participatory processes to unravel and explore these, incorporating investors as principal agents responsible for rejigging value-laden practices in concert with other investors and developing realistic test trials in the environmental conditions and EBM options. Such a research format is radically different from conventional science modes and requires careful attention at each step in the process. Co-developer stakeholders or 'use briefers' (since they are no longer described as end-users) are positioned to appreciate the confluence of forces with new possibilities (context), and socioecological science is embedded in new relations. Note that MSP played no important role in this emergent assembling project.

\section{Conclusion}

Following Affolderbach et al. (2012), we argue that a 'remapping' of the oceans is well underway. We think that, under the Blue Economy, diverse actors are assembling networks and making territories around many specific projects. Business, science and investor interests are being recruited into frontier projects, as exemplified by the activities of the World Oceans Forum and even the EU's Horizon2020 research funding round. These projects are diverse and not necessarily compatible with one another. They include MPAs, stock assessment assemblages, and aquaculture license areas, and these fisheries projects sit alongside prospecting licenses, communications and energy infrastructure, tourist attractions and routes and transport infrastructure.

The Blue Economy is an opportunity for assembling separate marine projects in multi-use and multi-user spaces. Organized as expert systems, each project will be assessed separately and with limited participation. Despite their many geographical attributes, the separate projects are promoted without regard to an overall geography or temporality of the projects. For these reasons, Blue Economy projects may arguably comprise an extension of the 'new' extractivism into ocean and coastal zones, where fragmented jurisdictions, ad hoc planning authorities, poorly developed planning practices and overlapping and missing jurisdictions compromise prospects for good governance in the name of sustainable oceans management. Allegations of fragmented governance in the oceans are a staple aspect of Blue Economy pronouncements, and this is especially so with regard to the fisheries, but the Blue Economy agenda is much broader than the established fisheries management systems. It includes management of EEZs, national coastal policies and coastal management planning as well as management of diverse activities in international waters.

In the Blue Economy, good governance is at issue and a crucial aspect of governance debates will be the roles of economic values for ocean environmental attributes and resources in sustainable ocean management. In this context, a range of assessment measures are already being used, but while 'integrated management' and 'spatial planning' are called for, it is unclear to what extent tensions with and adverse effects from other projects can be avoided or mitigated using these approaches. Nor are the sophisticated assessment frameworks - conservation management and assessment frameworks, appraisals of ecosystem services, livelihoods, good governance and socioeconomic resilience - that may assist in planning in marine and coastal environments proven or compatible in this use. Furthermore, the EC's Blue Economy vision recruits 
economic assessment practices - economic analysis of clusters, networks, regional development and innovation - into central roles in the overall project, which is premised on the identification of a new Blue Economy within the EU economy.

There are diverse bioeconomic projects operating, perhaps hidden, under Blue Economy initiatives, each of which assembles constellations of actors into networks and territories. Prominent among these projects are the EU's Blue Economy, MPA, aquaculture license areas, prospecting licenses and the spatial planning of transport corridors, port development and offshore renewable energy infrastructure. Established projects such as fisheries stock assessments for fisheries territories as part of sustainable yield management of capture fisheries tend to be taken-for-granted and not the focus for innovation. We have deliberately phrased these projects in geographic terms: these are all territorial projects as well as economic projects, with often unknown interdependencies and temporalities. Thus, we endorse Cardwell and Thornton's (2015) outline of an enormous geographic agenda in marine management, but we call for special attention by geographers to the management and scientific issues posed by the Blue Economy. What awareness exists of the constitutive impulses (Bridge, 2011) of these historically and geographically new relations being assembled as Blue Economy? Is ongoing conceptual mapping of their coemergent and co-scaling character and content being conducted? Is there a focus on new possibilities and practices, choices, and collaborations, and, in the end, who is undertaking Blue Economy initiatives, and who is being invited into them and who is able to be invited in? The immensity of the Blue Economy challenge is not lost on academic and science administrator Jane Lubchenco who twittered from the 2014 World Ocean Summit, 'it's OK to use the oceans, but not to use them up' (The Economist, 2014b: 3). Social scientists and humanities scholars may not have a long track record of engagement with most of the emerging fields of study, yet, the globalizing presence of Blue Economy imaginaries and the rapidly forming arrangements around biology and economy suggest this must be rectified, and quickly.
By performing a mapping of the Blue Economy, by advocating the reassembling of the human and more than human in marine space and by reporting on experience within an actual example of science and policy interaction shaped by Blue Economy ideas, we have sketched examples of practices and power relations within the Blue Economy. In the process, we have found that there may, in some circumstances, be scope for geographers to enact alternative bioeconomic relations. The Blue Economy proposes a new 'trading environment' (Winder and Dix, 2016) - that is the place in which environments are traded as well as the environments that are traded there - that will allow the mobilization of environments on a massive scale for economic purposes. The scope for geographers to be engaged is enormous and, as ever, the bioeconomic projects that are already in play are replete with compromises, for researchers and for those involved. Our contribution shows enactive engagement by geographers in making the space-time configurations of new politics and possibilities. We argue that by considering the Blue Economy as diverse investment institutional projects geographers can identify how each initiative addresses bioeconomic relations, what ethical and political challenges of dealing with ocean space they entail and how bioeconomic relations can be made differently under Blue Economy relations. We believe that such enactive engagement should be a priority for geographers when dealing with Blue Economy projects.

\section{Acknowledgements}

We are appreciative of the award of a Visiting Fellowship by the Center for Advanced Studies, Ludwig-Maximilians-Universität (LMU) Munich to Richard Le Heron in 2014, which led to discussions on Blue Economy initiatives. The authors thank those geographers actively researching marine questions who answered our early efforts to ascertain the level of awareness of Blue Economy ideas among geographers. Earlier versions of the article were presented at the Centre for Advanced Studies, LMU Munich in June 2014, a special session 'Geography and the Blue Economy' at the Annual Meeting of the Canadian Association of Geographers, Vancouver 2015, at the University of Vechta, November 2015 and at the School of Environment, The University of Auckland, 
March 2016. Gordon Winder acknowledges the research assistance of Marie Aschenbrenner at the LMU Munich. Richard Le Heron acknowledges dialogue with Nick Lewis over emergence, assembling and experimentation in Blue Economy ideas. We are grateful for the insightful suggestions of three anonymous referees and the Editors.

\section{Declaration of Conflicting Interests}

The author(s) declared no potential conflicts of interest with respect to the research, authorship, and/or publication of this article.

\section{Funding}

The author(s) received no financial support for the research, authorship, and/or publication of this article.

\section{Note}

1. This presentation to the Centres of Research Excellence Fund (CoRE) Assessment panel was dismissed as inadequate. Many of the CoRE project team became active in Sustainable Seas NSC.

\section{References}

2 Mers Seas Zeeën (2014) Programme. Lille, Interreg IV A 2 Mers Seas Zeeën. Available at: http://www.inter reg4a-2mers.eu (accessed September 2015).

Abu Dhabi Declaration, January 1 (2014). Available at: http://www.BE_Summit.declaration_20_Jan_14_ FINAL (accessed 1 July 2014).

Affolderbach J, Clapp RA and Hayter R (2012) Environmental bargains and boundary organizations: remapping British Columbia's Great Bear Rainforest. Annals of the Association of American Geographers 102(6): 1391-1408.

Agnew J (2009) Making the strange familiar: geographical analogy and global geopolitics. Geographical Review 99(3): 426-443.

Allan J (2012) White Paper on Michigan's Blue Economy. East Lansing: Michigan Land Policy Institute.

Allen J (2012) A more than relational theory? Dialogues in Human Geography 2(2): 190-193.

Anderson B and McFarlane C (2011) Assemblage and geography. Area 43(2): 124-127.

Anderson J and Peters K (eds.) (2014) Water Worlds: Human geographies of the ocean. Aldershot: Ashgate Publishing.
Anderson B, Kearnes M, McFarlane C, et al. (2012) On assemblages and geography. Dialogues in Human Geography 2(2): 171-179.

Arkema K, Abramson S and Dewsbury B (2006) Marine ecosystem-based management: from characterisation to implementation. Frontiers in Ecology and the Environment 4(10): 525-532.

Bailey I and Caprotti F (2014) The green economy: Functional domains and theoretical directions of enquiry. Environment and Planning A 46(8): 1797-1813.

Bakker K (2010) The limits of 'neoliberal natures': debating green neoliberalism. Progress in Human Geography 34(6): 715-735.

Ban N, Mills M, Tam J, et al. (2013) Social-ecological approach to conservation planning: embedding social considerations. Frontiers in Ecology and the Environment 11(4): 194-202.

Baragwanath L and Lewis N (2014) Waiheke Island. In: Howland P (ed.) Social, Cultural and Economic Impacts of Wine in New Zealand. London: Routledge, pp. 211-226.

Bargh M (2014) A Blue Economy for Aotearoa New Zealand. Environment Development Sustainability 16: 459-470.

Bear C (2012) Assembling the sea: materiality, movement and regulatory practices in the Cardigan Bay scallop fishery. Cultural Geographies 20(1): 21-41.

Bennett N, Govan H and Satterfield T (2015) Ocean grabbing. Marine Policy 57: 61-68.

Brenner N (1999) Globalisation as reterritorialisation: the rescaling of urban governance in the European Union. Urban Studies 36(3): 431-451.

Bridge G (2011) Resource geographies I: making carbon economies, old and new. Progress in Human Geography 35(6): 820-834.

Bromley D W (2011) Abdicating responsibility: the deceits of fisheries policy. Fisheries 34(6): 280-290.

Brown V, Harris J and Russell J (2010) Tackling Wicked Problems: Through the Transdisciplinary Imagination. London and Washington, DC: Earthscan, pp. 69-70.

Bulkeley H (2005) Reconfiguring environmental governance: Towards a politics of scales and networks. Political Geography 24(8): 875-902.

Cardwell E and Thornton T (2015) The fisherly imagination: the promise of geographical approaches to marine management. Geoforum 64: 157-167. 
Castree N and Braun B (eds.) (2001) Social Nature: Theory, Practice and Politics. Malden: Blackwell.

Castree N, Adams W, Barry J, et al. (2014) Changing the intellectual climate. Nature Climate Change 4: 763-768.

Chatham House (2014) The Blue Economy: Seychelles' Vision for Sustainable Development in the Indian Ocean. London: Chatham House. Available at: https://www.chathamhouse.org/sites/files/chatham house/field/field_document/20140611BlueEconomy. pdf (accessed September 2015).

Clarke A (2003) Situated analyses: grounded theory mapping after the postmodern turn. Symbolic Interaction 26: 553-576.

Cohen A and Bakker K (2014) The eco-scalar fix: rescaling environmental governance and the politics of ecological boundaries in Alberta, Canada. Environment and Planning D 32(1): 128-146.

Cook B, Rickards L and Rutherford I (2015) Geographies of the Anthropocene. Geographical Research 53(3): 231-243.

Coombes B, Johnson JT and Howitt R (2014) Indigenous geographies III: Methodological innovation and the unsettling of participatory research. Progress in Human Geography 38(6): 845-854.

Crutzen P and Stoermer E (2000) Global Change newsletter. The Anthropocene 41: 17-18.

Dalby S (2009) Security and Environmental Change. Cambridge: Polity.

Douvere F and Ehler C N (2001) Ecosystem-based marine spatial management: An evolving paradigm for the management of coastal and marine places. Management 90: 77-88.a

Douvere F and Ehler CN (2009) New perspectives on sea management: Initial findings from European experience with marine spatial planning. Journal of Environmental Management 90: 77-88.

Douvere F, Maes F, Vanhulle A, et al. (2007) The role of marine spatial planning in sea use management: the Belgian case. Marine Policy 31(2): 182-191.

Drankier P (2012) Embedding marine spatial planning in national legal frameworks. Journal of Environmental Policy and Planning 14(1): 7-27.

EC (2014a) Blue Growth, Brussels, European Commission. Communication from the Commission to the European Parliament, The Council, The European Economic and Social Committee and the Committee of the Regions EC Blue Growth year. Available at:
http://eur-lex.europa.eu/legal-content/EN/ALL/? uri=CELEX:52012DC0494 (accessed 31 August 2015).

EC (2014b) Innovation in the Blue Economy: Realising the Potential of Our Seas and Oceans for Jobs and Growth. Brussels. COM(2014) 254 final2.

Ehler C N and Douvere F (2009) Marine Spatial Planning: A Step-by-step Approach toward Ecosystem-based Management. Intergovernmental Oceanographic Commission and Man and the Biosphere Programme. IOC Manual and Guides, 53. ICAM Dossier 6. Paris: UNESCO.

Elden S (2010) Land, terrain, territory. Progress in Human Geography 34(6): 799-817.

Fagan R and Le Heron R (1994) Reinterpreting the geography of accumulation: the global shift and local restructuring. Environment and Planning D, Society and Space 16(3): 265-285.

Fissel D, Babin M, Bachmayer R, et al. (2012) 40 Priority Research Questions for Ocean Science in Canada. Ottawa: The Council of Canadian Academies.

Flannery W and Cinnéide M O (2008) Marine spatial planning from the perspective of a small seaside community in Ireland. Marine Policy 32: 980-987.

Fletcher R (2013) How I learned to stop worrying and love the market: Virtualism, disavowal and public secrecy in neoliberal environmental conservation. Environment and Planning D, Society and Space 31: 796-812.

Fletcher S and Potts J (2007) Ocean citizenship: an emergent geographical concept. Coastal Management 35: 511-524.

Halpern B, Bruno J, Casey K, et al. (2008) A global map of human impact on marine ecosystems. Science 319 : 948-952.

Hamilton-Hart N and Stringer C (2016) Upgrading and exploitation in the fishing industry: Contributions of value chain analysis. Marine Policy 63: 166-171.

Jay S (2012) Marine space: manoeuvring towards a relational understanding. Journal of Environmental Policy and Planning 14(1): 81-96.

Jay S, Ellis G and Kidd S (2012) Marine spatial planning: a new frontier? Journal of Environmental Policy and Planning 14(1): 1-5.

Kidd S and Ellis G (2012) From the land to the sea and back again? Using terrestrial planning to understand the process of marine spatial planning, Journal of Environmental Policy and Planning 14(1): 49-66. 
Kim W and Mauborgne R (2005) Blue ocean strategy: how to create uncontested market space and make competition irrelevant. Available at: https://www.blue oceanstrategy.com/ (accessed 5 November 2014).

Klauser F (2012) Thinking through territoriality: introducing Claude Raffestin to Anglophone sociospatial theory. Environment and Planning D: Society and Space 30(1): 106-120.

Kobayashi A (2009) Situated knowledge, reflexivity. In: Kitchin $\mathrm{R}$ and Thrift $\mathrm{N}$ (eds) International Encyclopedia of Human Geography. Oxford: Elsevier, pp. 138-143.

Lambert D, Martins L and Ogborn M (2006) Currents, visions and voyages: Historical geographies of the sea. Journal of Historical Geography 32: 479-493.

Larner W and Le Heron R (2002) The spaces and subjects of a globalising economy: a situated exploration of method. Environment and Planning D: Society and Space 20(6): 753-774.

Le Heron R (2013) Emerging neo-liberalising economic and governmental processes in New Zealand's land-based sector: a post-structural political economy framing using emergence diagrams. Applied Geography 45: 392-401.

Le Heron R (2014) The marine economy. Presentation to the CoRE Assessment Panel, Oceanic Sciences, 11 April.

Le Heron E (2015) Attempts to assemble Blue Economy imaginaries in New Zealand in 2014 - a conference centred investigation. Paper presented at the Canadian Association of Geographers Annual Meeting, Vancouver, BC, 3 June.

Le Heron E, Lewis N and Le Heron R (2013) Wine economy as geographically open assemblage? Thinking beyond sector, region and terroir. New Zealand Geographer 69(3): 221-234.

Le Heron R, Campbell H, Thrush S, et al. (2014) Land-coast-ocean: A new science object, new policy object and new value propositions. Presentation to Ministry for the Environment, Wellington, 11 December.

Le Heron R, Campbell H, Lewis N, et al. (eds.) (2016a) Biological Economies: Experimentation and the Politics of Agri-food Frontiers. London: Routledge.

Le Heron R, Lewis N, Fisher K, et al. (2016b) Non-sectarian scenario experiments in socioecological knowledge building for multi-use marine environments. Insights from New Zealand's Marine Futures project. Marine Policy 67: 10-21.
Lewis N (2015) Developing a Blue Economy definition. Email Correspondence with R Le Heron 7 August.

Lewis N, Le Heron R, Campbell C, et al. (2013) Assembling biological economies: region shaping initiatives in making and retaining value. New Zealand Geographer 69(3): 180-196.

Lewis N, Le Heron R, Campbell H, et al. (2016) Assembling generative approaches in agrifood research. In: Le Heron R, Carolan M, Lewis N and Carolan M (eds) Biological Economies: Experimentation and the Politics of Agri-food Frontiers. Milton Park, Abingdon, OXON, and New York: Routledge, 1-20.

Li T (2014) What is land? Assembling a resource for global investment. Transactions Institute of British Geographers 39(4): 589-602.

Liu S (2011) China's marine economy. East Asia Forum. Available at: http://www.eastasiaforum.org/2011/11/ 17/china-s-marine-economy/ (accessed 16 September 2015).

Lockie S (2014) Climate, scenario-building and governance: Comprehending the temporalities of socioecological change. In: Lockie S, Sonnerfield D and Fisher D (eds) Routledge International Handbook of Social and Environmental Change. London: Routledge, pp. 95-105.

Mansfield B (2004) Neoliberalism in the oceans: "Rationalization," property rights, and the commons question. Geoforum 35(3): 313-326.

Mansfield B (2007) Articulation between neoliberal and state-oriented environmental regulation: fisheries privatization and endangered species protection. Environment and Planning A 39(8): 1926-1942.

Massey E and Rees E (2004) Sustainable utilization of fisheries as governmentality: constraining the potential for ecosystems-based management. New Zealand Geographer 60(1): 25-35.

McAfee K (2014) The post and future politics of green economy and REDD+. In: Land R and Stephan B (eds) The Politics of Carbon Markets. London: Routledge, pp. 237-260.

Müller M (2015) Assemblages and actor-networks: rethinking socio-material power, politics and space. Geography Compass 9(1): 27-41.

Munroe D, McSweeney K, Olson J, et al. (2014) Using economic geography to reinvigorate land-change science. Geoforum 52: 12-21. 
Nel A (2014) Sequestering Market Environmentalism: Geographies of Carbon Forestry and Unevenness in Uganda. Unpublished PhD Thesis, University of Otago, Dunedin, New Zealand.

Ogborn M (2005) Editorial: Atlantic geographies. Social and Cultural Geography 6: 379-385.

Parsons E, Favaro B, Aguirre A, et al. (2014) Seventy-one important questions for the conservation of marine biodiversity. Conservation Biology 28(5): 1206-1214.

Pascual M, Borja A, Eede S V, et al. (2011) Marine biological valuation mapping of the Basque continental shelf (Bay of Biscay), within the context of marine spatial planning. Estuarine, Coastal and Shelf Science 95(1): 186-198.

Pauli G (2010) The Blue Economy: 10 Years, 100 Innovations, 100 Million Jobs. Taos: Our Planet, Paradigm Books.

Penders B and Goven J (2010) Nutrigenomics and the stewardship of scientific promises. Biotechnology Journal 5(9): 909-912.

Peters K, (2010) Future promises for contemporary social and cultural geographies of the sea. Geography Compass 4(9): 1260-1272.

Pomeroy R and Douvere F, (2008) The engagement of stakeholders in the marine spatial planning process. Marine Policy 32: 816-822.

Rayner S (2012) Uncomfortable knowledge: the social construction of ignorance in science and environmental policy discourses. Economy and Society 41(1): $107-125$.

Reilly B (2015) Re-assemblying Airports: A New Conceptual and Empirical Geography of Auckland International Airport. Unpublished MSc thesis, University of Auckland, Auckland.

Rockstrom J, Steffen W, Noone K, et al. (2009) Planetary boundaries: exploring the sage operating space for humanity. Nature 461: 472-475.

Rosin C, Dwiartama A, Grant D, et al. (2013) Using provenance to create stability: State-led territorialisation of Central Otago as assemblage. New Zealand Geographer 69: 235-248.

Rossiter J, Costi G, Moreno C, et al. (2015) Marine-space assemblages: Towards a different praxis of fisheries policy and management. Applied Geography 59: 142-149.

RSNZ (2012) Future Marine Resource Issue: Emerging Issues. Wellington: Royal Society of New Zealand.
Sakhuya V (2014) Blue Economy: an agenda for the Indian government. Center for International Maritime Security. Available at: http://cimsec.org/blue-econo my-agenda-indian-government/12996 (accessed 16 September 2015).

Schaefer N and Barale V (2011). Maritime spatial planning: Opportunities and challenges in the framework of the EU Integrated maritime policy. Journal of Coastal Conservation 15(2): 237-245.

Shahneaz A and Salma U (2015) Prospects and challenges of Blue Economy in Bangladesh. The Daily Observer, 28 January 2015.

Silver J, Gray N, Campbell L, et al. (2015) Blue Economy and competing discourses in international oceans governance. Journal of Environment and Development 24(2): 1-26.

Silvey R and Rankin K (2011) Development geography: Development studies and political geographical imaginaries. Progress in Human Geography 35(5): 696-704.

Simon S and Randalls S (2016) Geography, ontological politics and the resilient future. Dialogues in Human Geography 6(1): 3-18.

Simpson S (2011) Sustainability: the blue food revolution. Scientific American 304(2): 55-61.

Smith HD, Ballinger RC and Stojanovic TA (2012) The spatial development basis of marine spatial planning in the United Kingdom. Journal of Environmental Policy and Planning 14(1): 29-47.

Solnit R and Snedeker R (2012) Unfathomable City: a New Orleans Atlas. San Francisco: University of California Press.

Sparke M (2013) Introducing Globalization - Ties, Tensions, and Uneven Development. London: Wiley Blackwell.

St.Martin K (2010) Towards a cartography of the commons: Constituting the political and economic possibilities of space. Professional Geographer 61(4): 493-507.

Steinberg PE (2013) Of other seas: metaphors and materialities in maritime regions. Atlantic Studies 10(2): 156-169.

Steinberg PE and Peters K (2015) Wet ontologies, fluid spaces: Giving depth to volume through oceanic thinking. Environment and Planning D: Society and Space 33: 247-264.

Tam C-L (2015) Branding Wakatobi: Marine place identity, development and legitimation by science. Paper 
presented in Geography and the Blue Economy, Special Session, Canadian Association of Geographers Annual Meeting, Vancouver, Canada.

Tsing A (2005) Friction: An Ethnography of Global Connection. Princeton: Princeton University Press.

UN (2013) Blue Economy Concept Paper. Available at: http://www.Sustainabledevelopment.un.org (accessed 1 July 2014).

Wacquant L (2015) For a sociology of flesh and blood. Qualitative Sociology 38: 1-11.

Winder GM (2006) Seafarer's gaze: Queen Street business and Auckland's archipelago. New Zealand Geographer 62(1): 50-64.

Winder GM and Dix A (eds) (2016) Trading Environments: Frontiers, Commercial Knowledge and Environmental Transformation, 1750-1990. London:
Routledge, in the Environment and Society Series, series editors Heike Egner and Bernhard Glaeser.

Winder GM (ed.) (2017) Fisheries Management and Quota Transfer: In the Wake of Bio-Economic Rationalization. Berlin: Springer.

Winder GM and Le Heron R (2015) Geography and the Blue Economy. Paper presented at Canadian Association of Geographers Annual Meeting, Vancouver, Canada, 3 June 2015.

Winder GM and Rees E (2010) Fish and boats: fisheries management issues in Northland. New Zealand Geographer 66(2): 152-168.

World Ocean Council (2014) Business forum, industry leadership in ocean governance and the Blue Economy. Available at: http://www.oceancouncil.org/site/ (accessed 20 June 2014). 